\title{
CREATING PROMOTIONAL MIX AND IMPROVING PHYSICAL EVIDENCE TO ATTRACT POTENTIAL CUSTOMERS OF SUCI SHOELAB
}

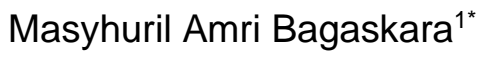 \\ Rambat Lupiyoadi ${ }^{2}$ \\ 1,2 Universitas Indonesia
}

*Corresponding Author: masyhuril.bagaskara@gmail.com

\begin{abstract}
The increasing number of MSMEs in Indonesia creates even more competition among businesses, especially during the COVID-19 pandemic. This difficult situation causes a decline in revenue and forces MSMEs in Indonesia to find strategies to survive. This study aims at helping an MSME in the shoe laundry industry called Suci Shoelab. This study employs qualitative and business coaching methods. The data were collected through interviews with the MSME owners and the employees as well as questionnaires given to customers. Several analytical methods, namely Business Model Canvas (BMC), Porter's Five Forces analysis, PESTEL analysis, Service Marketing Mix, SWOT analysis, TOWS analysis, Gap analysis, and Pareto Analysis, were used to identify the problems and generate solutions. The findings revealed that the MSME had not promoted its products consistently and the location of Suci Shoelab was unknown to many potential customers. The MSME improved the promotional activity and placed signage to enhance its physical evidence to address this issue. Sales promotions and digital/internet marketing were also used for the promotional mix, and discount prices and drop stations were applied as promotional programs. For increasing its physical evidence, the MSME placed signage at the store to attract potential customers. After the solutions were applied, the sales of the MSME increase.
\end{abstract}

Keywords: Promotional Mix, MSMEs, Business Model Canvas, PESTEL analysis, SWOT Anaylsis, TOWS Analysis, Gap Analysis, Pareto Analysis

\section{INTRODUCTION}

Indonesia's shoe industry is one of the fastest-growing industries nationally and ranks fourth globally after China, India, and Vietnam. In 2018, Indonesia produced 1.41 billion pairs of shoes and contributed $4.6 \%$ to shoe production 
worldwide. Furthermore, Kemenperin records in 2018 show a 9.42\% increase in the leather, leather products, and shoe industry, higher than in 2017, when the growth was only $2.22 \%$ (Kemenperin, 2019). The increase in production and sales of shoes in Indonesia is seen as opportunities by many people, as shoe-related businesses such as shoe laundries, shoe restorations, and shoe treatments business have increased significantly. Suci Shoelab is an MSME that provides shoe treatment services such as shoe laundry and shoe restoration. The MSME, which name originally was 'Look Waxy', has been running since 2015. In 2019, the name changed to Suci Shoelab for rebranding purposes. Suci Shoelab has a competitive advantage as it offers high-quality shoe laundry service at an affordable price. However, the business is unable to reach its full capacity each month. Hence, focusing on marketing activities to raise potential customers' awareness of Suci Shoelab is necessary to increase sales.

Interviews with employees and observations of the business were conducted to analyze and identify the problems encountered by Suci Shoelab. The gap and Pareto analysis results indicate that there were five main issues faced by Suci Shoelab. However, this study only focused on the two main issues, namely creating a promotional mix and improving physical evidence.

\section{LITERATURE REVIEW}

The service marketing mix is one of the marketing tools widely used by marketers to communicate their products. Zeithaml et al. (2013) state that a marketing mix consists of company components utilized to communicate with and satisfy the customers. The traditional marketing mix consists of only four components, not including a customer interface. Adding three additional components from Wirtz and Lovelock (2016), the seven components of service marketing mix are (1) Product, (2) Price, (3) Place, (4) Promotion, (5) People, (6) Process and (7) Physical Evidence.

Moreover, promotion refers to sellers' efforts to create information and persuasion channels to sell goods and services or promote ideas. A promotional mix is a tool used by marketers to execute the communication objectives of a business (Belch \& Belch, 2018). There are six elements in a promotional mix: (1) Advertising, (2) Direct Marketing, (3) Digital/Internet Marketing, (4) Sales Promotion, (5) Publicity/Public Relations, and (6) Personal Selling.

The service environment plays an important role in delivering a service as a correct environment will help create positive emotional reactions and enhance customer's perception and retention (Baker et al., 2002). In addition, Wirtz \& Lovelock (2016) state that the service environment is crucial in shaping service experience and increases customer satisfaction, especially in services with a high 
level of interaction with customers. Moreover, Zeithaml et al. (2013) explain that physical evidence is an environment for service delivery and buyer-seller interaction.

\section{METHOD}

This study employed a qualitative method using MSME Suci Shoelab as a case study. Business coaching was conducted based on primary and secondary data. The primary data were obtained through in-depth interviews, observations, and surveys. Indepth interviews to gather information on the business process and its financial and marketing information were conducted with the owner and employees. Observations on customers' behavior and the employees-customers interaction were carried out during the business hours. Further, an online survey was given to 142 customers to identify the awareness of people around the Suci Shoelab physical store. The secondary data used in this study were journals regarding the promotional mix and physical evidence. External and internal data analyses were conducted to identify the gaps and Pareto analysis. The result identified Suci Shoelab's main problems and helped to determine potential applicable solutions.

\section{RESULT AND DISCUSSION}

\section{Creating Promotional Mix Implementation}

Suci Shoelab's first problem was the lack of promotional activities due to ineffective marketing channel utilization. Hence, Suci Shoelab needs to increase its promotional activities to boost sales and attract new customers. To address this issue, in the promotional mix, the MSME focused on sales promotion and digital/internet marketing, while business coaching generated two strategies, namely price discounts and drop stations.

The price discount strategy directed the MSME to give customers a flat rate of Rp 50.000 for every pair of shoes cleaned. This strategy was aimed at attracting customers to use Suci Shoelab's service and increase the business's sales. This promotional activity was part of consumer-oriented sales promotion, giving buyers incentives in price discount to boost short term sales. This promotional strategy was considered the most effective and suitable as the business was almost closed down. During the COVID-19 pandemic, the MSME has lost at least the sales for two months. Therefore, the business needs to attract customers and regain sales to survive the pandemic. The other promotional strategy was giving free pickup and delivery for shoes cleaned to accommodate customers afraid of visiting the store directly due to the risk of contracting COVID-19.

The second promotion strategy was the establishment of a drop station, a tradeoriented sales promotion. Suci Shoelab partnered with agents collecting customers' shoes from their area and then bringing them to the store in BSD city. The business 
currently has three agents located in Bintaro, Pesanggrahan, and Cempaka Putih. The agents get Rp40,000 in commission for every pair of shoes brought to the store. The establishment of drop stations has increased the number of customers and sales. It has contributed to a large percentage of the MSME's sales each month.

Digital/internet marketing supports sales promotions by promoting the business' social media accounts. This promotional strategy increases Suci Shoelab sales immediately after the store was forced to close for two months due to the COVID19 pandemic.

Table 1. Percentage Contribution of Drop Station

\begin{tabular}{|c|c|c|c|c|c|c|}
\hline \multirow{2}{*}{ Month } & \multicolumn{3}{|c|}{ Revenue } & \multirow{2}{*}{\multicolumn{2}{|c|}{ Total Revenue }} & \multirow{2}{*}{$\begin{array}{l}\text { \% Drop } \\
\text { Station }\end{array}$} \\
\hline & & op Station & Suci Shoelab & & & \\
\hline July & $\mathrm{Rp}$ & $1,400,000.00$ & $\operatorname{Rp} 5,240,000.00$ & $\mathrm{Rp}$ & $6,640,000.00$ & $21 \%$ \\
\hline August & $\mathrm{Rp}$ & $2,680,000.00$ & $\operatorname{Rp} 5,570,000.00$ & $\mathrm{Rp}$ & $8,250,000.00$ & $32 \%$ \\
\hline September & $\mathrm{Rp}$ & $3,000,000.00$ & $\operatorname{Rp} 2,335,000.00$ & $\mathrm{Rp}$ & $5,335,000.00$ & $56 \%$ \\
\hline October & $\mathrm{Rp}$ & $2,120,000.00$ & $\operatorname{Rp} 2,860,000.00$ & $\mathrm{Rp}$ & $4,980,000.00$ & $43 \%$ \\
\hline November & $\mathrm{Rp}$ & $1,360,000.00$ & $\operatorname{Rp} 4,535,000.00$ & $\mathrm{Rp}$ & $5,895,000.00$ & $23 \%$ \\
\hline
\end{tabular}

\section{Suci Shoelab Revenue 2020}

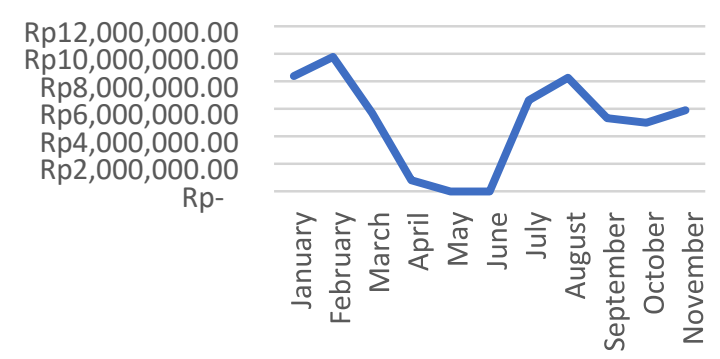

Figure 1. Suci Shoelab Total Revenue in 2020

\section{Improving Physical Evidence Implementation}

The mini-survey conducted to people around Suci Shoelab physical store found that more than $50 \%$ of respondents were unaware of the store was located near the area. Hence, placing signage was the best strategy to improve Suci Shoelab's physical evidence and attractiveness to customers. The signage was originally planned to be installed during the business coaching process. However, the application was postponed as two-month closure forced Suci Shoelab to focus on promotional activities to boost sales. The installation of the signage was conducted after the financial condition of the business improved. 


\section{CONCLUSION}

The business coaching given to Suci Shoelab has generated solutions for their problems. A promotional mix and improving physical evidence as the solutions were proved to be effective as the business increases its sales and gains new customers during the COVID-19 pandemic. The business' social media have also become more active in communicating and promoting products. The improvement of physical evidence by installing the signage was conducted after the business's financial condition got stable. Regardless of the aforementioned improvement, the study was limited as it only covered one service of Suci Shoelab, a shoe laundry service. Investigation on the MSME's other service, such as shoe restoration, is suggested to be conducted to get a more holistic picture of its situations and challenges.

\section{REFERENCES}

Baker, J., Parasuraman, A., Grewal, D. and Voss, G.B. (2002), "The influence of multiple store environment cues on perceived merchandise value and patronage intentions," Journal of Marketing, Vol. 66 No. 2, pp. 120-41.

Belch, G. E., \& Belch, M. A. (2018). Advertising and Promotion: An Integrated Marketing Communications Perspective (11th Ed.). McGraw Hill Education.

"Kemenperin: Indonesia Produsen Alas Kaki Terbesar Keempat Di Dunia." Edited by Investor Daily, Kementerian Perindustrian, 2019, kemenperin.go.id/artikel/20539/IndonesiaProdusen-Alas-Kakl-TerbesarKeempat-Di-Dunia.

Wirtz, J., \& Lovelock, C. (2016). Services Marketing. In Services Marketing (8th edition). WORLD SCIENTIFIC (U.S.).

Zeithaml, V.A., M.J. Bitner, D.D. Gremler. 2013. Services Marketing: Integrating Customer Focus Across the Firm 6 thed. Mc.Graw-Hill. Boston. 